\title{
PENGARUH LINGKUNGAN KERJA NON FISIK, KOMPENSASI, KEPUASAN KERJA, TERHADAP KINERJA KAYAWAN, DAN KOMITMEN ORGANISASI SEBAGAI VARIABEL MEDIASI (Studi Kasus di PT. Bagus Conveksi Branch Paragon Mall Semarang)
}

\author{
Frida Putri Suryaningrum \\ Fakultas Ekonomi Universitas Pandanaran Semarang \\ arumfrida2@gmail.com \\ Andi Tri Haryono \\ Fakultas Ekonomi Universitas Pandanaran Semarang \\ anditriharyono@unpand.ac.id \\ Dheasey Amboningtyas \\ Fakultas Ekonomi Universitas Pandanaran Semarang \\ dheasey@unpand.ac.id
}

\begin{abstract}
Abstrak: Penelitian ini bertujuan untuk mengetahui Pengaruh Lingkungan Kerja Non Fisik, Kompensasi, Kepuasan Kerja, Terhadap Kinerja Kayawan, Dan Komitmen Organisasi Sebagai Variabel Intervening Studi Kasus Pada PT. Bagus Conveksi Cabang Paragon Mall City Semarang. Populasi dalam penelitian ini adalah karyawan PT. Bagus Conveksi Cabang Paragon Mall City Semarang.Sampel dalam penelitian ini diambil dengan metode Purposive Sampling.Data dianalisis dengan menggunakan uji normalitas, uji asumsi klasik, uji koofisiendeterminasi, uji F dan Uji hipotesis.Hasil Pada variabel lingkungan kerja secara statistik berpengaruh terhadapkomitmen organisasi.Pada variabel kompensasi secara statistik berpengaruh terhadap komitmen organisasi Pada variabel kepuasan kerja secara statistik berpengaruh terhadap komitmen organisasi Pada variabel lingkungan kerja secara statistik berpengaruh terhadap kinerja karyawan.Pada variabel kompensasi secara statistik berpengaruh terhadap kinerja karyawan.Pada variabel kepuasan kerja secara statistik berpengaruh terhadapkinerja karyawan Pada variabel komitmen organisasi secara statistik berpengaruh terhadap kinerjakaryawan.
\end{abstract}

Kata Kunci : Lingkungan Kerja ; Kepuasan Kerja ; Komitmen Organisasi ; Kinerja Karyawan

\section{PENDAHULUAN}

Sejalan dengan perkembangan ilmu pengetahuan dan teknologi yang sangat cepat perusahaan tidak dapat mengelak dari persaingan yang muncul di tengah globalisasi dan gelombang perkembangan bisnis, guna menghadapi persainagn yang sangat kompetitif tersebut, perusahaan hendaknya mampu memanfaatkan, mengelola, dan memberdayakan sumber daya yang dimiliki secara optimal dan memegang prinsip efisiensi dan 
efektifitas Perusahaan merupakan suatu organisasi yang mendukung pembangunan negara di bidang ekonomi, perusahaan memerlukan faktor-faktor yang saling terkait satu sama lain. Faktor-faktor tersebut antara lain tenaga kerja, modal, bahan baku, dan teknologi. Fungsi dasar didirikannya perusahaan adalah menambah masukan (input) yang berupa sumber daya yaitu bahan baku, modal, teknologi dan lain sebagainya menjadi keluaran (output) yang berupa pemuas kebutuhan (barang dan jasa) sebagai timbal balik bagi berbagai pihak yang terlibat dan berkepentingan terhadap perusahaan. Salah satu sumber daya perusahaan atau organisasi yang sangat penting dan mendasar untuk disiapkan adalah sumber daya manusia yang sangat besar pengaruhnya terhadap keberhasilan perusahaan. Karena dengan bahan baku yang melimpah, modal yang besar, dan teknologi yang canggih tidak akan menghasilkan manfaat bila tidak ada yang mengelola dan mengolahnya. Dengan berbagai sumber daya yang dimiliki oleh perusahaan tersebut diharapkan karyawaan dapat mengelola dengan baik demi kemajuan perusahaan.Seperti yang dikatakan Louis A. Allen dalam As'ad (2015) tentang pentingnya manusia dalam menjalankan roda industri: "Betapapun sempurnanya rencana-rencana, organisasi, dan pengawasan serta penelitiannya, bila mereka tidak dapat menjalankan tugasnya dengan minat dan gembira maka suatu perusahaan tidak akan mencapai hasil sebanyak yang sebenarnya dapatdicapai”.

Dengan demikian, dapat ditarik kesimpulan bahwa aspek sumber daya manusia memegang peran yang cukup besar untuk memajukan perusahaan. Sumber daya manusia merupakan aset yang dapat meningkatkan keberhasilan perusahaan. Kemampuan sumber daya manusia merupakan

kunci utama untuk mampu menghadapi persaingan dalam era globalisasi, kemampuan ini sering disebut keunggulan kompetitif. Paradigma baru dalam pengelolaan kegiatan perusahaan adalah pendayagunaan sumber daya manusia.Hal tersebut di cerminkan dari peran sumber daya manusia dalam kegiatan perusahaan.

Tidak hanya sumber daya manusia yang berperan penting untuk kemajuan perusahaan, tetapi juga lingkungan kerja yang baik juga dibutuhkan dalam suatu organisasi. Menurut Robbins (2006), Pegawai yang peduli akan lingkungan kerja, baik untuk kenyamanan pribadi maupun untuk memudahakan tugas yang lebih baik. Pengaturan suhu ruangan kerja, cahaya, dan faktor-faktor lingkungan lain seharusnya tidak ekstrem (terlalu banyak atau terlalu sedikit), misalnya terlalu panas atau remang-remang untuk pencahayaan yang ada diruangan tersebut. Disamping itu, kebanyakan pegawai lebih menyukai bekerja dalam fasilitas yang bersih, relatif modern, dan dengan alat-alat dan peralatan yang memadai.

Selain lingkungan kerja yang dapat menunjang peningkatan produktifitas kerja karyawan, kompensasi juga salah satu penunjang kinerja karyawan untuk bisa lebih baik.Kompensasi itu sendiri adalah semua pendapatan yang berbentuk uang, barang langsung atau tidak langsung yang diterima karyawan sebagai imbalan 
atas jasa yang diberikan kepada perusahaan. Menurut Hasibuan (2005), besarnya kompensasi harus diusahakan sedemikian rupa sehingga mampu mengikat karyawa. Hal ini juga sangat penting, sebab bila kompensasi yang diberikan kepada karyawan terlalu kecil bila dibandingakan perusahaan lain pada umumnya, bila ada kesempatan menimbulkan kecenderungan pindahnya karyawan itu sendiri dari perusahaan satu keperusahaan yang lain. Hal ini harus diperhatikan terutama bagi karyawan yang penting sebab merek ini pada umumnya telah diberikan pelatihan dengan biaya yang cukup besar (Nitisemito,2006).

Penilaian kinerja (performance apprasial) adalah proses pengamatan dan pengevaluasian kinerja seorang pegawai, pencatatan penilaian, dan pemberian umpan balik terhadap pegawai. Penilaian kerja terdiri atas langkah-langkah pengamatan dan penilaian kinerja pegawai, pencatatan dan umpan balik.Selama penilaian kinerja pegawai, manajermanajer terampil akan memberikan umpan balik dan pujian atas unsur yang dapat diterima dari kinerja pegawai.

Perusahaan membutuhkan karyawan yang mempunyai kinerja (job performance) yang tinggi.Kinerja karyawan merupakan suatu tindakan yang dilakukan karyawan dalam melaksanakan pekerjaan yang diberikan (Handoko, 2008). Kinerja (performance) juga dapat di artikan sebagai gambaran mengenai tingkat pencapaian pelaksanaan suatu kegiatan, program, kebijakan dalam mewujudkan sasaran, tujuan, misi, dan visi organisasi yang tertuang dalam mewujudkan planning suatuorganisasi.

\section{TINJAUAN PUSTAKA Lingkungan Kerja Non Fisik}

Didalam lingkungan kerja tidak hanya memperhatikan dari segi lingkungan fisik saja, akan tetapi lingkungan kerja non fisik merupakan salah satu hal penting dalam meningkatkan efektivitas kerja karyawan. Karena lingkungan kerja fisik maupun lingkungan kerja non fisik dapat mempengaruhi physiology dan psychologis karyawan dalam bekerja.

Pengertian lingkungan kerja menurut Amstrong (Bagus Kisworo, 2012) the work environment consist of the system of work, the design of jobs,workingconditions, and the ways in which people are treated at work by their managers and coworkers. Lingkungan kerja terdiri dari sistem kerja, desain pekerjaan, kondisi kerja, dan cara-cara di mana orang diperlakukan di tempat kerja dengan manajer dan rekan kerja mereka.

\section{Kompensasi}

Karyawan yang bekerja dalam sebuah organisasi pasti membutuhkan kompensasi atau imbalan yang cukup dan adil, bila tidak cukup kompetitif di banding dengan organisasi atau perusahaan lain. Sistem kompensasi yang baik akan sangat mempengaruhi semangat kerja dan dan produktivitas dari seseorang. Suatu sistem kompensasi yang baik perlu didukung oleh metode secara rasional yang dapat menciptakan seseorang digaji atau diberi kompensasi sesuai tuntunan pekerjaannya. Menurut Hasibuan (2017). Kompensasi adalah semua pendapatan yang berbentuk uang, barang langsung atau tidak langsung 
yang diterima karyawan sebagai imbalan atas jasa yang diberikan kepada perusahaan. Pembentukan sistem kompensasi yang efektif merupakan bagian penting dari manajemen sumber daya manusia karena membantu, menarik, dan mempertahankan pekerjaan pekerjaan yang berbakat.Selain itu sistem kompensasi perusahaan memiliki dampak terhadap kinerja strategi.

\section{Kepuasan Kerja}

Locke dalam Wijono (2011) berpendapat bahwa kepuasan kerja sebagai suatu tingkat emosi yang positif dan menyenangkan individu.Kepuasan kerja adalah suatu hasil perkiraan individu terhadap pekerjaan atau pengalaman positif dan menyenangkan dirinya.Sedangkan menurut Robbins dalam Wibowo (2008) kepuasan kerja adalah sikap umum terhadap pekerjaan seseorang yang menunjukkan perbedaan antara jumlah penghargaan yang diterima pekerja dan jumlah yang mereka yakini seharusnya mereka terima. Menurut Moh.As'ad dalam Sunyoto (2012) kepuasan Kerja (job satisfaction) adalah keadaan emosional yang menyenangkan atau tidak menyenangkan dimana para karyawan memandang pekerjaannya. Keith Davis dalam Mangkunegara (2011) mengemukakan bahwa "job satisfaction is thefavorableness or unfavorrableness with employees view their work" (kepuasan kerja adalah perasaan menyokong atau tidak menyokong yang dialami pegawai dalambekerja).

\section{Komitmen Organisasi} Komitmen Organisasi bisa tumbauh disebabkan karena individu memiliki ikatan emosional terhadap perusahaan yang meliputi dukungan moral dan menerima nilai yang ada di dalam perusahaan serta tekad dari dalam diri untuk mengabdi pada perusahaan. Komitmen Organisasional adalah suatu keadaan dimana seorang karyawan memihak organisasi tertentu serta tujuan-tujuan dan keinginannya untuk mempertahankan keanggotaan dalam organisasi tersebut.Jadi keterlibatan pekerjaan yang tinggi berarti memihak pada pekerjaan tertentu seorang individu, sementara Komitmen Organisasional yang tinggi berarti memihak organisasi yang merekrut individu tersebut (Robbins,2008). Menurut Luthans (2012) menyatakan bahwa Komitmen Organisasi adalah, sikap yang merefleksikan loyalitas karyawan pada organisasi dan proses berkelanjutan dimana anggota organisasi mengekspresikan pertahiannya terhadap organisasi, dan keberhasilan serta kemajuan yang berkelanjutan.

\section{Kinerja Karyawan}

Menurut Sunyoto (2012) kinerja adalah sesuatu hasil kerja yang dicapai oleh seseorang karyawan dalam menyelesaikan pekerjaan yang dibebankan kepadanya.Dalam Sutrisno (2010) dinyatakan bahwa, kinerja karyawan adalah hasil kerja karyawan dilihat pada aspek kualitas, kuantitas, waktu kerja, dan kerjasama untuk mencapai tujuan yang sudah ditetapkan olehorganisasi.

Menurut Simamora (2013) kinerja adalah tingkat dimana karyawan mencapai persyaratan 
pekerjaan. Kinerja individu menggambarkan sampai seberapa jauh seseorang telah melaksanakan tugas pokoknya sehingga dapat memberikan hasil yang ditetapkan oleh kelompok atau intistusi (Nasution, 2010).Organisasi harus percaya bahwa untuk mencapai keunggulannya, perlu mengusahakan kinerja individu yang setinggitingginya. Pada dasarnya kinerja individu akan mempengaruhi kinerja tim dan pada akhirnya mempengaruhi kinerja organisasi secara keseluruhan.

\section{Pengembangan Hipotesis}

Hipotesis yang dikemukakan dalam penelitian ini adalah : menurut arti kata hipotesa berasal dari dua penggalan kata, yaitu "hypo" artinya "dibawah" dan "thesa" artinya "kebenaran" atau "pendapat". Selanjutnya penulisannya menjadi hipotesa menurut Pedoaman PUEBI.

Hipotesis dari penelitian ini adalah: kenyamanan karyawan dalam bekerjasama dengan karyawan lain maupun dengan atasannya juga merupakan faktor penting untuk meningkatkan loyalitas karyawan terhadap perusahaan. Kenyaman yang dimaksud disini merupakan kenyamanan yang dilihat dari segi lingkungan kerja non fisik yang dirasakan oleh karyawan.Menurut

Sedarmayanti

(2001),

lingkungan kerja non fisik adalah semua keadaan yang terjadi yang berkaitan dengan hubungan kerja, baik hubungan dengan atasan maupun hubungan sesama rekan kerja, ataupun hubungan dengan bawahan.Oleh karena itu perusahaan harus menjaga hubungan kerja antar pegawainya dengan baik agar hasil dari kerjasama tersbut sesuai dengan yang diinginkan. Lingkungan kerja tersebut akan mendorong karyawan yang bersangkutan untuk bergairah dalam bekerja dan pada akhirnya menjadi profesionalitas berupa loyalitas karyawan kepada perusahaan. Karyawan yang merasa nyaman saat bekerja akan cenderung ingin tetap bekerja didalam kenyamanannya tersebut. Maka hipotesis ynag diajukan adalah sebagai berikut:

H1: Lingkungan kerja non fisik dapat berpengaruh terhadap komitmen organisasi pada PT. BAGUS CONVEKSI cabang Paragon Mall CitySemarang

Saat ini bagi perusahaan yang ingin tetap bersaing dengan para pesaingnya, komitmen karyawannya merupakan hal penting yang menjadi perhatian agar karyawan berkualitas yang mereka miliki tetap akan berjuang bersama untuk mencapai tujuan perusahaan. Terdapat banyak aspek yang dapat mempengaruhi komitmen para karyawan tersebut, salah satunya adalah kompensasi yang diberikan oleh perusahaan.Bragg

mengatakan bahwa karyawan yang berkomitmen melakukan pekerjaan lebih baik dibandingkan dengan karyawan yang tidak berkomitmen dan organisasi dengan pekerja yang berkomitmen lebih baik secara finansial daripada organisasi yang tidak berkomitmen.Banyak penelitian menunjukkan terdapat banyak jenis penghargaan yang dapat menyebabkan kinerja dan komitmen yang tinggi. Salah satu yang mendapat perhatian makin besar adalah penghargaan terhadap kenyataan bahwa banyak karyawan memiliki tanggung jawab atas pekerjaan dan keluarga, dan ketika 
organisasi membantu mereka menangani kewajiban tersebut komitmen mereka akan meningkat (Luthans, 2005). Maka hipotesis ynag diajukan adalah sebagai berikut:

$\mathrm{H} 2$ : Kompensasi yang diberikan oleh perusahaan dapat berpengaruh terhadap komitmen organisasi pada PT. BAGUS CONVEKSI cabang Paragon Mall City Semarang

Sumber daya manusia merupakan sumber daya paling vital sekaligus sulit untuk diprediksi, sehingga kepuasan kerja dari karyawan merupakan sesuatu yang utama dan krusialdalam manajemen (Papoola \& Adio, 2009). Dengan begitu kepuasan kerja karyawan perluuntuk diperhatikan, karena dengan karyawan yang puas akan menimbulkan dampak positifbagi organisasi juga. Pada penelitian lain yang dilakukan oleh Chen et al (2010) menunjukan tidak terdapat pengaruh yang signifikan antara kepuasan kerja terhadap komitmen profesi. Penelitian yang dilakukan di perusahaan asuransi Taiwan tersebut justru menunjukan pengaruh yang positif signifikan antara kepuasan kerja terhadap komitmen organisasi.Walaupun demikian pada penelitian yang dilakukan Chen tersebut menunjukan kepuasan kerja memiliki hubungan yang cukup kuat dengan komitmen profesi dan saling berkaitan. Maka hipotesis yang diajukan adalah sebagai berikut:

H3: Kepuasan kerja yang dirasakan oleh karyawan PT. BAGUS CONVEKSI cabang Paragon Mall City Semarang dapat berpengaruh terhadap komitmen organisasi

Komitmen Organisasi bisa tumbauh disebabkan karena individu memiliki ikatan emosional terhadap perusahaan yang meliputi dukungan moral dan menerima nilai yang ada di dalam perusahaan serta tekad dari dalam diri untuk mengabdi pada perusahaan. Menurut Mowday (1982 dalam Sopiah, 2008) Komitmen organisasi merupakan dimensi perilaku penting yang dapat digunakan untuk menilai kecenderungan karyawan untuk bertahan sebagai anggota organisasi.Komitmen organisasi merupakan identifikasi dan keterlibatan seseorang yang relatif kuat terhadap organisasi komitmen organisasi adalah keinginan anggota organisai untuk mempertahankan keanggotaannya dalam organisasi dan bersedia berusaha keras bagi pencapaian tujuan organisasi.Semakin baik atau semakin kuat komitmen seorang karyawan kepada perusahaan tersebut maka semakin tinggi kinerja para karyawan. Maka hipotesis yang diajukan adalah sebagaiberikut :

H4: Komitmen organisasidapat berpengaruh terhadap kinerja karyawan PT. BAGUS CONVEKSI cabang Paragon Mall City Semarang Menurut Hasibuan (2017) Kompensasi adalah semua pendapatan yang berbentuk uang, barang langsung atau tidak langsung yang diterima karyawan sebagai imbalan atas jasa yang diberikan kepada perusahaan.Pembentukan sistem kompensasi yang efektif merupakan bagian penting dari manajemen sumber daya manusia karena membantu, menarik, dan mempertahankan pekerjaanpekerjaan yang berbakat.Selain itu sistem kompensasi perusahaan memiliki dampak terhadap kinerja strategi.Menurut Handoko (2014) kompensasi adalah segala sesuatu yang diterima para karyawan sebagai balas jasa untuk kerja mereka. 
Program-program kompensasi juga penting bagi perusahaan, karena mencerminkan upaya organisasi untuk mempertahankan sumber daya manusia. Semakin besar kompensasi yang diberikan oleh perusahaan maka semakin baik kinerja para karyawan yang ada di perusahaan. Maka hipotesis ynag diajukan adalah sebagai berikut:

H5: Lingkungan kerjanon fisik yang kondusif dapat berpengaruh terhadap kinerja karyawan PT. BAGUS CONVEKSI cabang Paragon Mall CitySemarang

Menurut Herman Sofyandi (2008), definisi Lingkungan Kerja adalah suatu bentuk susunan atau rangkaian faktor yang menjadi pengaruhi kinerja, yang bisa dilihat dari fungsi, aktivitas manajemen dalam organisasi. Lingkungan kerja menurut Sedarmayanti (2011) adalah keseluruhan alat perkakas dan bahan yang dihadapi, lingkungan sekitarnya dimana seseorang bekerja, metode kerjanya, serta pengaturan kerjanya baik sebagai perseorangan maupun sebagai kelompok. Dan menurut Danang Sunyoto (2012) Lingkungan Kerja adalah segala hal yang ada disekitar para pekerja yang dapat mempengaruhi dirinya dalam menjalankan tugas, misalnya untuk hal ini ialah kebersihan, peneranagn , musik, dan lain-lain. Semakin baik dan semakin mendukung suatu lingkungan yang diberikan oleh perusahaan maka akan semakin baik kinerja para pegawainya. Maka hipotesis yang diajukan adalah sebagai berikut:

H6: Kompensasiyang diberikan oleh PT. BAGS CONVEKSI cabang Paragon Mall City Semarang dapat berpengaruh terhadap kinerja karyawan
Locke dalam Wijono (2011) berpendapat bahwa kepuasan kerja sebagai suatu tingkat emosi yang positif dan menyenangkan individu.Kepuasan kerja adalah suatu hasil perkiraan individu terhadap pekerjaan atau pengalaman positif dan menyenangkan dirinya. Sedangkan menurut Robbins dalam Wibowo (2008) kepuasan kerja adalah sikap umum terhadap pekerjaan seseorang yang menunjukkan perbedaan antara jumlah penghargaan yang diterima pekerja dan jumlah yang mereka yakini seharusnya mereka terima.Menurut Moh.As'ad dalam Sunyoto (2012) Kepuasan Kerja (jobsatisfaction) adalah keadaan emosional yang menyenangkan atau tidak menyenangkan dimana para karyawan memandang pekerjaannya. Semakin puas para karyawan dengan apa yang diberikan oleh perusahaan maka akan semakin tinggi kinerja para karyawan tersebut. Maka hipotesis yang diajukan adalah sebagai berikut:

H7: Kepuasan kerjayang didapat pada PT. BAGUS CONVEKSI cabang Paragon Mall Sberpengaruh terhadap kinerja karyawan

Komitmen organisasional adalah suatu keadaan dimana seorang karyawan memihak organisasi tertentu serta tujuantujuan dan keinginannya untuk mempertahankan keanggotaan dalam organisasi tersebut.Jadi keterlibatan pekerjaan yang tinggi berarti memihak pada pekerjaan tertentu seorang individu, sementara komitmen organisasional yang tinggi berarti memihak organisasi yang merekrut individu tersebut (Robbins, 2008). Semakin baik komitmen karyawan kepada perusahaan maka akan semakin baik lingkungan kerja 
yang disediakan oleh perusahaan sehingga dapat meningkatkan kinerja para karyawan. Maka hipotesis yang diajukan adalah sebagai berikut :

H8: Komitmen organisasi yang dijalankan oleh karyawan dapat memediasi lingkungan kerjanon fisik terhadap kinerja karyawan pada PT. BAGUS CONVEKSI cabag Paragon Mall CitySemarang

\begin{tabular}{ccr}
\multicolumn{2}{c}{ Komitmen } & \multicolumn{2}{c}{ organisasional } \\
adalah & suatu keadaan dimana \\
seorang & karyawan memihak
\end{tabular}
organisasi tertentu serta tujuantujuan dan keinginannya untuk mempertahankan keanggotaan dalam organisasi tersebut.Jadi keterlibatan pekerjaan yang tinggi berarti memihak pada pekerjaan tertentu seorang individu, sementara komitmen organisasional yang tinggi berarti memihak organisasi yang merekrut individu tersebut (Robbins, 2008). Semakin baik komitmen karyawan kepada perusahaan maka akan semakin baik kompensasi yang diberikan oleh perusahaan sehingga dapat meningkatkan kinerja para karyawan. Maka hipotesis yang diajukan adalah sebagai berikut :

H9: Komitmen organisasi oleh karyawan PT. BAGUS CONVEKSI cabang Paragon Mall City Ssemarang dapat memediasi kompensasi terhadap kinerja karyawan.

Komitmen organisasional adalah suatu keadaan dimana seorang karyawan memihak organisasi tertentu serta tujuantujuan dan keinginannya untuk mempertahankan keanggotaan dalam organisasi tersebut.Jadi keterlibatan pekerjaan yang tinggi berarti memihak pada pekerjaan tertentu seorang individu, sementara komitmen organisasional yang tinggi berarti memihak organisasi yang merekrut individu tersebut (Robbins, 2008). Semakin baik komitmen karyawan kepada perusahaan maka akan semakin baik kepuasan kerja seorang karyawan terhadap perusahaan sehingga dapat meningkatkan kinerja para karyawan. Maka hipotesis yang diajukan adalah sebagai berikut :

H10: Komitmen organisasi dapat memediasi kepuasan kerja terhadap kinerja karyawan PT. BAGUS CONVEKSI cabang Paragon Mall City Semarang

\section{Populasi dan Sampel}

Populasi adalah wilayah generalisasi yang terdiri atas obyek atau subyek yang mempunyai kualitas dan karakteristik tertentu yang ditetapkan oleh peneliti untuk dipelajari kemudian ditarik kesimpulannya. Jadi, populasi bukan hanya orang, tetapi juga obyek dan benda-benda alam yang lain. Populasi juga bukan sekedar jumlah yang ada pada obyek atau subyek yang dipelajari, tetapi meliputi seluruh karakteristik/sifat yang dimiliki oleh subyek atau obyek itu Sugiyono(2010). Populasi yaitu sekelompok orang, kejadian atau segala sesuatu yang mempunyai karakteristik tertentu Indriantoro (2009).Populasi yang menjadi objek penelitian ini adalah karyawan PT.Bagus Conveksi, dengan jumlah populasi 40 orang.

Sampel adalah bagian dari jumlah karakteristik yang dimiliki oleh populasi tersebut sampel yang diambil dari populasi tersebut harus betul-betul representative (mewakili) Sugiyono (2012).Sampel yang digunakan dalam penelitian ini diambil dengan teknik pengambilan sensus, yaitu teknik penentuan 
sampel dengan menggunakan seluruh data yang ada atau seluruh karyawan karyawan PT. Bagus Conveksi.Pengambilan metode sensus sendiri digunakan untuk pengumpulan data apabila seluruh elemen pupolasi diselidiki satu per satu.Data yang diperoleh tersebut merupakan hasil pengolahan sensus disebut sebagai data yang sebenarnya (true value) atau sering disebut parameter.

\section{HASIL DAN PEMBAHASAN Uji Validitas}

Uji validitas digunakan untuk mengukur sah atau valid tidaknya suatu kuisioner (Ghozali, 2009). Suatu kuisioner dikatakan valid jika pertanyaan pada kuisioner mampu menggungkapkan sesuatu yang akan diukur oleh kuisioner tersebut. Jadi, validitas adalah mengukur apakah pertanyaan dalam kuisioner yang sudah dibuat betul-betul dapat mengukur apa yang hendak diukur. Uji validitas dapat diketahui dengan melihat $r$ hitung dan $r$ tabel $(\mathrm{N}-2)$, maka pertanyaan tersebut dikatakan valid.

Berdasarkan hasil tabel di atas, pengujian validitas menunjukkan nilai R- Hitung untuk semua variabel penelitian >R- Tabel $(0,165)$, sehingga dapat diasumsikan bahwa data kuesioner valid.

\section{Uji Reliabilitas}

Uji reliabilitas adalah alat uji untuk mengukur kuesioner yang merupakan indikator dari variabel (Ghozali, 2006:45). Menurut Nunally (Dalam Ghozali 2006: 45) suatu variabel dikatakan reliabel, jika nilai alpha $>0,7$.

Berdasarkan hasil tabel di atas, pengujian reliabilitas menunjukkan nilai cronbach's alpha instrument untuk semua variabel penelitian mempunyai nilai cronbach alpha > 0,70 sehingga dapat dikatakan bahwa instrument dalam penelitian ini adalah reliabel dan layak untuk digunakan.

\section{Uji Normalitas}

Uji normalitas bertujuan untuk menguji apakah dalam data, variabel terikat dengan variabel bebas keduanya mempunyai hubungan distribusi normal atau tidak.Data yang baik adalah memiliki distribusi data normal atau mendekati normal (Ghozali, 2001).

Berdasarkan tabel diatas residual model 1 dan model 2 menghasilkan nilai 0.233 dan 0,910 di atas batas nilai 0.05.Hal ini berarti data terdistribusi dengan normal. Sehingga dengan kenormalan data pada penelitian ini maka dapat dilanjutkan ketahap berikutnya.

\section{Uji Multikolinearitas}

Uji multikolinearitas bertujuan untuk menguji apakah model regresi ditemukan adanya korelasi antar variabel bebas (independen). Salah satu cara untuk mendeteksi ada atau tidaknya multikolinearitas adalah dengan melihat nilai Variance Inflation Factor(VIF).

Berdasarkan tabel di atas diketahui bahwa semua nilai VIF variabel bebas dibawah 10 dan nilai tolerance di atas 0.10 dapat dinyatakan bahwa dalam regresi tidak terjadi multikolinearitas.

\section{Uji Heteroskedastisitas}

Uji Heteroskedastisitas bertujuan menguji apakah dalam model regresi terjadi ketidaksamaan variance dari residual satu pengamatan ke pengamatan yang lain. Jika variance dari residual satu pengamatan ke pengamatan lain tetap, maka disebut 
homokedastisitas dan jika berbeda disebut heteroskedastisitas.Model regresi yang baik adalah homoskedastisitas atau tidak heteroskedastisitas. Kebanyakan data crossection Dari hasil uji glejser dapat disimpulkan bahwa salah satu variabel independen yang digunakan dalam penelitian ini tidak terjadi heteroskedastisitas yang dibuktikan nilai signifikansi semua variabel > 0,05 .

\section{Analisis Regresi Linier Berganda}

Analisis regresi digunakan untuk mengetahui apakah variabel bebas secara bersama-sama mempengaruhi variabel terikat dan untuk mengukur kekuatan hubungan antara dua variabel atau lebih serta menunjukkan arah hubungan antara variabel bebas dan variabelterikat.

Persamaan regresi linier berganda yang dipergunakan untuk menganalisis variabel tersebut adalah sebagaiberikut:

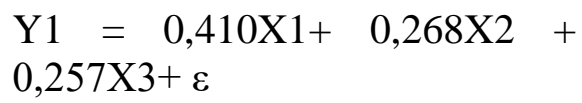

Persamaan regresi linier berganda yang dipergunakan untuk menganalisis variabel tersebut adalah sebagaiberikut:

$\mathrm{Y} 2=0,319 \mathrm{X} 1+0,227 \mathrm{X} 2+0,268$ $\mathrm{X} 3+0,322 \mathrm{Y} 1+\varepsilon$

1. Pada variabel lingkungan kerja non fisik diperoleh nilai $t$ hitung $=3,165$ lebih besar dari tabel sebesar 1.661 dan nilai signifikansi sebesar $0,003<0,05$ dengan demikian H1diterima. Halini berarti variabel lingkungan kerjanon fisik secara statistik berpengaruh terhadapkomitmen organisasi.
2. Pada variabel kompensasi diperoleh nilai $\mathrm{t}$ hitung $=$ 2,320lebih besar dari ttabel sebesar 1.661 dan nilai signifikansi sebesar $0,025<0,05$ dengan demikian H1diterima. Halini berarti variabel kompensasi secara statistik berpengaruh terhadap komitmen organisasi

3. Pada variabel kepuasan kerja diperoleh nilai $\mathrm{t}$ hitung $=$ 2,054lebih besar dari ttabel sebesar 1.661 dan nilai signifikansi sebesar $0,046<0,05$ dengan demikian H1diterima. Halini berarti variabel kepuasan kerja secara statistik berpengaruh terhadap komitmen organisasi.

4. Pada variabel lingkungan kerjanon fisik diperoleh nilai $\mathrm{t}$ hitung $=3$,389lebih besar dari ttabel sebesar 1.661 dan nilai signifikansi sebesar $0,002<0,05$ dengan demikian H1diterima. Halini berarti variabel lingkungan kerjanon fisik secara statistik berpengaruh terhadap kinerja karyawan.

5. Pada variabel kompensasi diperoleh nilai $\mathrm{t}$ hitung $=$ 2,169lebih besar dari ttabel sebesar 1.661 dan nilai signifikansi sebesar $0,036<$ 0,05 dengan demikian H1diterima. Halini berarti variabel kompensasi secara statistik berpengaruh terhadapkinerjakaryawan

6. Pada variabel kepuasan kerja diperoleh nilai $\mathrm{t}$ hitung $=$ 2,265lebih besar dari ttabel sebesar 1.661 dan nilai signifikansi sebesar $0,030<$ 
0,05 dengan demikian

H1diterima. Halini berarti variabel kepuasan kerja secara statistik berpengaruh terhadapkinerjakaryawan

7. Pada variabel komitmen organisasi diperoleh nilai $\mathrm{t}$ hitung $=2,899$ lebih besar dari ttabel sebesar 1.661 dan nilai signifikansi sebesar $0,006<$ 0,05 dengan demikian H1diterima. Halini berarti variabel kepuasan kerja secara statistik berpengaruh terhadapkinerjakaryawan.

\section{Kesimpulan}

Berdasarkan hasil analisis yang telah dilakukan pada bab sebelumnya dapat ditarik kesimpulan sebagai berikut :

1. Pada variabel lingkungan kerja non fisik diperoleh nilai $t$ hitung $=3,165$ lebihbesar dari ttabel sebesar 1.661 dan nilai signifikansi sebesar $0,003<$ 0,05 dengan demikian H1diterima. Halini berarti variabel lingkungan kerja secara statistik berpengaruh terhadapkomitmen organisasi.

2. Pada variabel kompensasi diperoleh nilai $\mathrm{t}$ hitung $=$ 2,320lebihbesar dari ttabel sebesar 1.661 dan nilai signifikansi sebesar $0,025<$ 0,05 dengan demikian H1diterima. Hal ini berarti variabel kompensasi secara statistik berpengaruh terhadap komitmen organisasi

3. Pada variabel kepuasan kerja diperoleh nilai t hitung $=2,054$ lebihbesar dari ttabel sebesar 1.661 dan nilai signifikansi sebesar $0,046<0,05$ dengan demikian H1 diterima. Hal ini berarti variabel kepuasankerja secara statistik berpengaruh terhadap komitmen organisasi

4. Pada variabel lingkungan kerja non fisik diperoleh nilai t hitung $=3,389$ lebihbesar dari ttabel sebesar 1.661 dan nilai signifikansi sebesar $0,002<$ 0,05 dengan demikian H1diterima. Halini berarti variabel lingkungan kerja secara statistik berpengaruh terhadapkinerjakaryawan.

5. Pada variabel kompensasi diperoleh nilai $\mathrm{t}$ hitung $=2,169$ lebihbesar dari ttabel sebesar 1.661 dan nilai signifikansi sebesar $0,036<0,05$ dengan demikian H1diterima. Halini berarti variabel kompensasi secara statistik berpengaruh terhadap kinerja karyawan.

6. Pada variabel kepuasan kerja diperoleh nilai t hitung $=2,265$ lebihbesar dari ttabel sebesar 1.661 dan nilai signifikansi sebesar $0,030<0,05$ dengan demikian H1diterima. Halini berarti variabel kepuasan kerja secara statistik berpengaruh terhadapkinerjakaryawan

7. Pada variabel komitmen organisasi diperoleh nilai $t$ hitung $=2,899$ lebihbesar dari ttabel sebesar 1.661 dan nilai signifikansi sebesar $0,006<$ 0,05 dengan demikian H1diterima. Halini berarti variabel kepuasan kerja secara statistik berpengaruh terhadap kinerja karyawan 
Saran

BagiPerusahaan

a. Kompensasi yang diberikan perusahaan lebih di tingkatkan lagi sehingga muncul kepuasan kerja padakaryawan.

b. Lebih menciptakan suasana kerja yang lebih kondusif sehingga membawa kenyamanan untuk karyawan ditempat kerja.

c. Agenda penelitian yang akan datang hendaklah mengembangkan lebih jauh model ini dengan menambahkan variabel lain yang masih ertat hubungannya, misalnya variabel jenjang karier, stress kerja, motivasi, ataupun indikator-indikator yang lain.

\section{DAFTAR PUSTAKA}

A.A.Anwar Prabu Mangkunegara. 2011. Manajemen Sumber Daya Manusia Perusahaan. PT. Remaja Rosda Karya, Bandung

Arifin, Eva. (2010). Broadcasting : To Be Broadcaster. Yogyakarta : Graha Ilmu, Yogyakarta.

As'ad, Mohammad. 2009. Seri Ilmu Sumber Daya Manusia: Psikologi Industri, Edisi IV. Yogyakarta: Liberty

Basri, Rivai. (2005). Performance Appraisal.Cetakan Pertama, PT Raja Grafindo Persada, Jakarta.

Daft, Richard. 2007. Management Majamemen. Jakarta:
Salemba Empat.

Danang, $\quad$ Sunyoto. 2012. Manajemen Sumber Daya Manusia. Jakarta: PT Buku Seru.

http://repository.upi.edu/1762 8/4/S_MBS_1001311_Biblio graphy

Darman, Syarif. 2009. Sumber Daya Manusia dan Produktivitas Kerja. Mandar Maju, Jakarta.

Edy, Sutrisno. 2011. Manajemen Sumber Daya Manusia. Penerbit: Jakarta, Kencana.

Fahrul, Budi Santoso. 2016. Pengaruh Pemberian Insentife dan Kompetensi Karyawan Terhadap Kinerja Karyawan PG. Madukismo Yogyakarta.Badan Penerbit Universitas NegeriYogyakarta.

Ghozali, Imam. 2011. Aplikasi Analisis Multivariate Dengan Program SPSS. Semarang: Badan Penerbit Universitas Diponegoro.

Hani, T. Handoko. 2014. Manajemen Personalia dan Sumber Daya Manusia.BPFEYogyakarta.Yogyakarta.

Hasibuan, Malayu S.P. 2016. Manajemen Sumber Daya Manusia. Edisi Revisi. Jakarta: Penerbit PT Bumi Aksara.

Heidjrachman Dan Husnan, Suad. 2002. Manajemen Personalia. Penerbit: BPFE UGM, Yogyakarta. 
Indriantoro, Nur., Bambang Supomo, 2009. Metodologi Penelitian Bisnis untuk Akuntansi dan Manajemen, Edisi Pertama.Yogyakarta : BPFE Yogyakarta.

Lies Indriyatni. 2009 .Analisis Pengaruh Kompensasi Dan Lingkungan Kerja Terhadap Produktifitas Kerja Perawat Dengan Kepuasan Kerja Perawat Dengan Kepuasan Kerja Sebagai Variable Mediasi Jurnal Ekonomi ManajemenAkuntansi, no. 26, th. xvi, pp.117-127 Luthans, Fred. 2012. Perilaku Organisasi. Yogyakarta: Penerbit Andi Offset.

Maulana, Agus. 2005. Sika (kekayaan anda yang paling berharga). Edisi Revisi. YKPN: Yogyakarta.

Marwansyah. 2016.Manajemen Sumber Daya Manusia. Edisi Dua. Cetakan keempat. Bandung: Alfabeta,CV

Maqfiranti, Sjahruddin. 2014. Pengaruh Stress dan Lingkungan Kerja Non Fisik terhadap Kinerja Karyawan Pada PT. Bumi Jasa Utama (Kallatransport).Bagian penerbit Universitas Makassar.Makassar.

Nasution.2010. Berbagai Pendekatan dalam Proses Belajar dan Mengajar. Jakarta: Bumi Aksara.

Robbins, Stephen P. dan Timothy A. Judge. 2008. Perilaku Organisasi Edisi ke-12, Jakarta: Salemba Empat.

Robbins, Stephen P., Coulter, Mary.
(2007). Manajemen Edisi Kedelapan Jilid 2. PT Indeks. Robbins. Stephen. P., Coulter. Mary. (2012). Management.Eleventh Edition. Jakarta: England.

Sedarmayanti. 2011. Manajemen Sumber Daya Manusia.

Reformasi Birokrasi dan Manajemen Pegawai Negeri Sipil, Cetakan Kelima, PT Refika Aditama, Bandung.

Simamora, Henry. (2014). Manajemen Sumber Daya Manusia.Yogyakarta: Bagian Penerbitan Sekolah Tinggi Ilmu Ekonomi YKPN Utama :jakarta. Sopiah. (2008). Perilaku Organisasi, Yogyakarta: Andi Offset.

Stoner, James A.F. (2006).Manajemen. Jilid I. Edisi Keenam. Salemba Empat, Jakarta.

Sugiyono. 2010. Metode Penelitian Pendidikan Pendekatan

Kuantitatif, kualitatif,dan $R \& D$. Bandung:Alfabeta

Sunyoto, Danang. 2013. Teori, Kuesioner \& Analisis Data Untuk Pemasaran.

Wahyu, K. dan Aji, H.S. (2014). Analisis Pengaruh Kualitas Pelayanan, Harga Dan bukti fisik Terhadap Kepuasan Konsumen.

Wibowo, 2016.Manajemen Kinerja, Edisi Kelima, PT.Rajagrafindo Persada Jakarta- 14240.

Wijono, Sutarto. (2010). Psikologi Industri dan Organisasi. Jakarta: Fajar InterpratamaOffset.

Umar, Husein. 2008. Manajemen Sumber Daya Manusia dalam 